\title{
SOURSOP LIQUOR PROCESSING: INFLUENCE OF THE PROCESS VARIABLES ON THE PHYSICAL AND CHEMICAL CHARACTERISTICS ${ }^{1}$
}

\author{
EMANUEL NETO ALVES DE OLIVEIRA ${ }^{2 *}$, DYEGO DA COSTA SANTOS ${ }^{3}$, YVANA MARIA GOMES DOS \\ SANTOS $^{3}$, PAULO RENATO BUCHWEITZ ${ }^{4}$, JOSIVANDA PALMEIRA GOMES ${ }^{3}$
}

\begin{abstract}
Soursop is a well-appreciated tropical fruit, both in natura and in the form of juices and nectars. Despite its wide acceptance, there is lack of its use in the preparation of other products, such as alcoholic beverages. The objective of this study was to prepare soursop liquors by varying the concentrations of pulp and sucrose syrup with different contents of total soluble solids and to evaluate the effects of these on the physical and chemical characteristics of the beverages. In the production process, the pulp (300, 400 and $500 \mathrm{~g})$ was macerated with distilled alcohol for 20 days, after which it was filtered, added to the syrup (50, 60 and $70{ }^{\circ}$ Brix), bottled in polyethylene bottles and subjected to an accelerated aging. All drinks resulted in alcohol levels $(15.25$ to $16.69 \% \mathrm{v} / \mathrm{v})$ and total sugars (12.63 to $17.97 \%)$ in accordance with the standards required by law. The experiments made with the lowest concentration of pulp showed the highest yields $(84.17$ and $85.25 \%)$. Firstorder models with interactions and $95 \%$ confidence intervals were obtained. The pulp consisted of the most significant factor, influencing the largest number of responses (yield, alcohol content, dry residue, titratable acidity, titratable acidity/soluble solids ratio and luminosity). The larger coefficient of determination $\left(\mathrm{R}^{2}\right)$ values were found in the models adjusted to the data of yield, dry residue, total soluble solids, titratable acidity and total sugars, which were significant and predictive, showing values greater than 0.97 .
\end{abstract}

Keywords: Alcoholic beverage. Annona muricata L.

\section{PROCESSAMENTO DE LICOR DE GRAVIOLA: INFLUÊNCIA DAS VARIÁVEIS DE PROCESSO NAS CARACTERÍSTICAS FÍSICAS E QUÍMICAS}

RESUMO - A graviola é uma fruta tropical muito apreciada, tanto in natura como na forma de sucos e néctares. Apesar de sua grande aceitação, existe a carência de sua utilização na elaboração de outros produtos, a exemplo de bebidas alcoólicas. Objetivou-se com o estudo elaborar licores de graviola variando-se as concentrações de polpa e xarope de sacarose com diferentes teores de sólidos solúveis totais e avaliar o efeito destas nas características físicas e químicas das bebidas. No processo produtivo, a polpa (300, 400 e $500 \mathrm{~g})$ foi macerada com destilado alcoólico durante 20 dias, sendo posteriormente filtrada e adicionada do xarope (50,60 e $70{ }^{\circ}$ Brix), envasada em garrafas de polietileno e submetida a um envelhecimento acelerado. Todas as bebidas resultaram teores alcoólicos $(15,25$ a 16,69\% v/v) e açúcares totais (12,63 a 17,97\%) em conformidade com os padrões exigidos pela legislação. Os experimentos elaborados com a menor concentração de polpa apresentaram os maiores rendimentos $(84,17$ e $85,25 \%)$. Obtiveram-se modelos de $1^{\mathrm{a}}$ ordem, com uma interação e intervalo de confiança de $95 \%$. A polpa constituiu-se no fator mais significativo, influenciando um maior número de respostas (rendimento, teor alcoólico, resíduo seco, acidez titulável, relação entre acidez titulável/sólidos solúveis e luminosidade). Os maiores valores de $\mathrm{R}^{2}$ foram encontrados nos modelos ajustados aos dados de rendimento, resíduo seco, sólidos solúveis totais, acidez titulável e açúcares totais, que foram significativos e preditivos, apresentando valores superiores a 0,97.

Palavras-chave: Annona muricata L.. Bebida alcoólica.

\footnotetext{
*Corresponding author

${ }^{1}$ Received for publication in $05 / 20 / 2014$; accepted in $11 / 04 / 2015$.

Part of the work of completion of the specialization course in food science at the Federal University of Pelotas the first author.

${ }^{2}$ Department of Food Technology, Instituto Federal de Educação, Ciência e Tecnologia do Rio Grande do Norte; Pau dos Ferros, RN, Brazil; emanuel.oliveira16@gmail.com.

${ }^{3}$ Academic Unit of Agricultural Engineering, Universidade Federal de Campina Grande; Campina Grande, PB, Brazil; dyego.csantos@gmail.com, yvana.mn@hotmail.com,josi@gmail.com.

${ }^{4}$ Academic Unit of Chemical Engineering, Universidade Federal de Pelotas; Pelotas, RS, Brazil; buchweitz@gmail.com.
} 


\section{INTRODUCTION}

The Brazilian northeastern region has favorable conditions for the cultivation of various fruitful species. Among these, the soursop tree (Annona muricata L.) has real economic potential or exploration potential (OLIVEIRA et al., 2009), due especially to the production of fruit with a pleasant taste and aroma, the soursop. Its great acceptability and proven industrial demand justify its cultivation and importance of the fruit in the producing areas (TEIXEIRA et al., 2006). According to Samarão et al. (2011), in addition to the consumption in natura, the soursop is used to obtain pulp, juice, nectar, canned goods and other processed products. Although the commercial importance in Brazil is considered of low expression compared to other fruits, the growing interest from the food industry, especially the juice industry, makes the soursop promising for export (SAMARÃO et al., 2011).

Despite the characteristics that make the soursop a fruit with high market potential, Lima et al. (2010) reported that the high perishability of soursop and the short shelf life after harvest have been responsible for high rates of losses and difficulties in the supply of traditional and potential markets for fresh fruit consumption. In this sense, the processing of the fruit is necessary for the preparation of various products, including alcoholic beverages, such as liquor.

According to Teixeira et al. (2007), the definition of "liquor" varies widely, depending on the author; however, they all mention the main elements that make up liquor: a beverage obtained "by mixing" that contains alcoholic components and precursors of flavor and sweetness. Brazilian law defines liquor as a beverage with an alcohol content of 15 to $54 \%(\mathrm{v} / \mathrm{v})$ at $20{ }^{\circ} \mathrm{C}$ and a percentage of sugar higher than $30 \mathrm{~g} / \mathrm{L}$, prepared with potable ethyl alcohol of agricultural origin or simple alcoholic distillate of agricultural origin or alcoholic beverages, with extracts or substances of vegetable or animal origin, flavoring and coloring substances and other additives added (BRASIL, 2009).

The handmade production of liquor is an interesting alternative for providing increased family income, for its processing requires simple technology, with the final product being sold at room temperature and with extensive shelf life (TEIXEIRA et al., 2005). The secrets of the quality of a fruit liquor are in the perfect combination of its components, especially the raw material (alcohol), the fruit used and the sugar as well as in the processes of preparation (infusion) and maturation, which will result in an integrated product with harmony between color, aroma and flavor.

According to Oliveira and Santos (2011), the maceration (infusion) is based on a unit operation, consisting of removing and/or extracting from a medium certain substances that are considered active principles (aromatic compounds, pigments, nutrients, etc.) by addition of a solvent (alcohol) during a certain period.

In the specialized literature, a wide range of studies can be found on fruit processing for the preparation of liquors, such as those involving passion fruit (DIAS et al., 2011), acerola (NOGUEIRA; VENTURINI FILHO, 2005), açaí (OLIVEIRA; SANTOS, 2011), pineapple (SIMÕES et al., 2011), banana (TEIXEIRA et al., 2007), tangerine (VIANA et al., 2011) and camu-camu (VIERA et al., 2010), among others. Notwithstanding, research on the use of soursop in the preparation of this type of drink was not found in the literature, which makes performing this work as another soursop processing alternative important.

Based on the foregoing information, the aim of this study was to prepare soursop liquors by varying the concentrations of pulp and sucrose syrup with different total soluble solids (TSS) and to evaluate the effects of these on the physical and chemical characteristics of the processed drinks.

\section{MATERIAL AND METHODS}

For the preparation of liquors, soursops at full ripeness from small producers of Campina GrandePB ( $7^{\circ} 13^{\prime} \mathrm{S}$ latitude, $35^{\circ} 52^{\prime} \mathrm{W}$ longitude and altitude of $552 \mathrm{~m}$ ), sucrose syrups with different TSS, prepared by concentrating a simmering solution of crystal sugar and water, and commercial alcohol (vodka) with an alcohol content of $39 \%(\mathrm{v} / \mathrm{v})$ were used.

The soursops were received at the Laboratory of Storage and Processing of Agricultural Products of the Federal University of Campina Grande, selected for by removal of injured fruits and sanitized in chlorine solution at a concentration of $200 \mathrm{ppm}$ for 15 minutes. The peeling was manual, using stainless steel knives, separating the pulp from the seeds, fibers and bark. An aliquot of the obtained pulp was subjected to physical and chemical analyses, and the remainder was bottled in polyethylene bags and stored at $-18{ }^{\circ} \mathrm{C}$ until early processing of the liquors.

The soursop pulp was analyzed in triplicate regarding the parameters of water content, total solids, ashes, lipids (Soxhlet), sugars (reducing sugars in glucose, non-reducing sugars in sucrose and total sugars in glucose), $\mathrm{pH}, \mathrm{TSS}$ and total titratable acidity (TTA) in citric acid according to methodologies of the Adolfo Lutz Institute (2008); density at $20{ }^{\circ} \mathrm{C}$, proteins (micro Kjeldahl) and total carbohydrates (by difference) according to the recommendations of the AOAC (2010); calorific value according to the Ministry of Health (BRASIL, 2005); ascorbic acid by the Tillmans method (AOAC, 1997), modified by Benassi and Antunes (1998); TSS/TTA ratio according to the Ministry of 
Agriculture, Livestock and Supply (BRASIL, 1986); water activity using an AQUA-LAB hygrometer, model CX-2, Decagon Devices; and color in a portable Hunter Lab Mini Scan XE Plus spectrophotometer, model $4500 \mathrm{~L}$, obtaining the parameters $\mathrm{L}^{*}, \mathrm{a}^{*}$ and $\mathrm{b}^{*}$, where $\mathrm{L}^{*}$ sets the luminosity $\left(\mathrm{L}^{*}=0\right.$ - black and $\mathrm{L}^{*}=100$ - white) and $\mathrm{a}^{*}$ and $\mathrm{b}^{*}$ are responsible for the chromaticity $\left(+\mathrm{a}^{*}\right.$ red and $-\mathrm{a}^{*}$ green; $+\mathrm{b}^{*}$ yellow and $-\mathrm{b}^{*}$ blue).

The soursop liquors were processed by a $2^{2}$ factorial experimental design method, with three experiments in the central point, resulting in a design matrix with seven experiments (Table 1). The objective was to evaluate the influence of the independent variables (concentrations of pulp and sucrose syrup with different contents of TSS) on the response variables (physical and chemical analyses) as well as their interactions.

In the production process of the liquors, the pulp was previously defrosted in a refrigerator $\left(\sim 4{ }^{\circ} \mathrm{C}\right)$ and macerated in cold vodka for 20 days, according to recommendations of Carvalho (2007), on previously sterilized glass containers. For the maceration, the pulp proportions itemized in Table 1 and $500 \mathrm{~mL}$ of commercial alcohol for each experiment were used.

Table 1. Design matrix with respective independent variables and their levels to prepare the soursop liquor.

\begin{tabular}{ccccc}
\hline & \multicolumn{2}{c}{ Coded values } & \multicolumn{2}{c}{ Actual values } \\
\cline { 2 - 5 } Experiment & $\mathrm{x}_{1}$ & $\mathrm{x}_{2}$ & $\begin{array}{c}\text { Pulp } \\
(\mathrm{g})\end{array}$ & $\begin{array}{c}\text { Syrup } \\
\left({ }^{\circ} \text { Brix }\right)\end{array}$ \\
\hline SL1 & -1 & -1 & 300 & 50 \\
SL2 & +1 & -1 & 500 & 50 \\
SL3 & -1 & +1 & 300 & 70 \\
SL4 & +1 & +1 & 500 & 70 \\
SL5 & 0 & 0 & 400 & 60 \\
SL6 & 0 & 0 & 400 & 60 \\
SL7 & 0 & 0 & 400 & 60 \\
\hline
\end{tabular}

SL1, SL2... SL7 - Soursop liquor.

The macerated material was subsequently filtered through a sieve with a thin layer of cotton to remove waste from the pulp, and $400 \mathrm{~mL}$ of sucrose syrup with 50, 60 and $70{ }^{\circ}$ Brix, according to the design of Table 1, were added for the purpose of promoting the rise of the sugar contents of the beverages and reducing their alcohol levels. The liquors were homogenized manually, placed in polyethylene bottles previously sterilized and subjected to accelerate aging in a bain-marie at $60{ }^{\circ} \mathrm{C}$ for 2 hours in order to develop aroma and flavor precursors, improving the beverage quality.

Later, the liquors were analyzed for the parameters of alcohol content and dry residue, according to methods of AOAC (2010); TSS, TTA in citric acid, $\mathrm{pH}$, total sugars in glucose, TSS/TTA ratio, water activity and color, according to methodologies described in the characterization of the soursop pulp; and income, calculated by the division of the mass of the liquor obtained by the sum of the mass of all ingredients (alcohol, syrup and pulp) used in the processing.

The experimental design was of randomized blocks with seven treatments and three replications, using the software Assistat version 7.5 beta. Data were subjected to analysis of variance, and mean comparisons were made by a Tukey test at 5\% probability. The effects of the independent variables on the dependent variables were evaluated by statistical analysis using the computer program Statistica version 6.0. The regressions were considered significant when the calculated $F$ value $\left(F_{c}\right)$ was higher than the tabulated $F$ value $\left(F_{t a b}\right)$ at the $5 \%$ level of significance $(p<0.05)$ and when the coefficient of determination of the regression $\left(\mathrm{R}^{2}\right)$ was exceeding 0.94 . When the $F_{c} / F_{\text {tab }}$ ratio was equal to or greater than 4.0 was also considered a significant predictive model. Response surfaces were generated only for the analyses that showed significant models.

\section{RESULTS AND DISCUSSION}

The results of the physical and chemical characterization of the soursop pulp used in the processing of liquors are shown in Table 2. A product with a high content of water, significant contents of carbohydrates, proteins and ashes and low content of lipids was observed, which explains the relatively low energetic value (less than 100 $\mathrm{kcal} / 100 \mathrm{~g}$ ).

With respect to the analyses of total solids (18.01\%), pH (3.97), TTA (0.89\%), TSS (19.50 Brix), total sugars $(7.22 \%)$ and ascorbic acid (22.17 $\mathrm{mg} / 100 \mathrm{~g}$ ), it was found that all values were in accordance with the recommendations of the Normative Ruling No. 01 of 2000 (BRASIL, 2000), which regulates the standards of identity and quality of the soursop pulp and establishes values for total solids, $\mathrm{pH}$, total acidity and TSS of at least $12.5 \%$, $3.50,0.6 \%$ and $9^{\circ}$ Brix, respectively, total sugar 
E. N. A. DE OLIVEIRA et al.

between 6.5 and $17 \%$ and ascorbic acid values of at least $10 \mathrm{mg} / 100 \mathrm{~g}$. Canuto et al. (2010), characterizing soursop from the country's northern region, also reported compliance of values obtained with respect to the current legislation.

Table 2. Physical and chemical composition of the soursop pulp.

\begin{tabular}{lclc}
\hline \multicolumn{1}{c}{ Parameter } & Mean value & \multicolumn{1}{c}{ Parameter } & Mean value \\
\hline Water content (\%) & $81.99 \pm 0.16$ & TSS/TTA ratio & $21.98 \pm 0.51$ \\
Total solids (\%) & $18.01 \pm 0.16$ & Reducing sugars (\%) & $6.74 \pm 0.08$ \\
Ashes (\%) & $0.66 \pm 0.04$ & Non-reducing sugars (\%) & $0.46 \pm 0.06$ \\
Proteins (\%) & $1.31 \pm 0.06$ & Total sugars (\%) & $7.22 \pm 0.14$ \\
Lipids (\%) & $0.01 \pm 0.00$ & Ascorbic acid $(\mathrm{mg} / 100 \mathrm{~g})$ & $22.17 \pm 0.09$ \\
Total carbohydrates (\%) & $16.12 \pm 0.34$ & Density at $20^{\circ} \mathrm{C}\left(\mathrm{g} / \mathrm{cm}^{3}\right)$ & $1.1370 \pm 0.03$ \\
Calorific value (kcal/100 g) & $69.80 \pm 1.25$ & Water activity $\left(\mathrm{a}_{\mathrm{w}}\right)$ & $0.986 \pm 0.00$ \\
pH & $3.97 \pm 0.05$ & Luminosity $\left(\mathrm{L}^{*}\right)$ & $63.59 \pm 0.08$ \\
Total titratable acidity (\%) & $0.89 \pm 0.02$ & Green intensity $\left(-\mathrm{a}^{*}\right)$ & $-2.33 \pm 0.13$ \\
Total soluble solids ( ${ }^{\circ}$ Brix) & $19.50 \pm 0.00$ & Yellow intensity $\left(+\mathrm{b}^{*}\right)$ & $12.49 \pm 0.24$ \\
\hline
\end{tabular}

TSS - Total soluble solids; TTA - Total titratable acidity in $\%$ citric acid.

The TSS/TTA ratio is similar to the value found by Marcellini et al. (2003) in soursop pulp (21.12) and higher than that found in other fruits, such as acerola (MACIEL et al., 2010), caja (CARVALHO et al., 2011) and passion fruit (CAVICHIOLI et al., 2008), where a greater sense of sweetness in soursop was found in relation to these fruits. Total sugars higher than $7 \%$ accumulated during the soursop ripening, and from that constituent, the reducing sugars were superior in comparison to the non-reducing sugars, which can be explained by the hydrolysis of starch during maturation.

A water activity greater than 0.98 attests to the need for hygienic processing of the pulp and storage in suitable conditions. With respect to the color parameters, the pulp showed to be clear $\left(\mathrm{L}^{*}\right)$, with a slight yellowish tint $\left(+b^{*}\right)$, which may have been influenced by high enzyme activity, and traces of slightly deep green (-a*). Canuto et al. (2010) found $\mathrm{L}^{*}$ values of 56.00, and Pereira et al. (2006) reported similar characteristics for color of the soursop pulp, with $\mathrm{L}^{*}$ between 45.82 and 68.14 , a* between 0.17 and 15.47 and $b^{*}$ between 10.54 and 14.77 .

In Tables 3 and 4, the average values of the physical and chemical analyses of the soursop liquors are shown. It was observed that all parameters analyzed showed significant effects at $1 \%$ probability by $\mathrm{F}$ tests, indicating that the syrups with different levels of TSS and the pulp concentrations used affected the physical and chemical characteristics of the drinks.

Table 3. Average values of the physical and chemical characterization of the soursop liquors.

\begin{tabular}{lccccccccc} 
EXP & \multicolumn{8}{c}{ Response } \\
\cline { 2 - 10 } & I (\%) & AC $(\% \mathrm{v} / \mathrm{v})$ & DR $(\%)$ & TTS $\left({ }^{\circ}\right.$ Brix $)$ & $\begin{array}{c}\text { TTA } \\
(\%)\end{array}$ & pH & $\mathrm{a}_{\mathrm{w}}$ & $\begin{array}{c}\text { Relation } \\
\text { TTS } / \text { TTA }\end{array}$ & $\begin{array}{c}\text { TS } \\
(\%)\end{array}$ \\
\hline SL1 & 84,17 & $16,69^{\mathrm{a}}$ & $27,56^{\mathrm{b}}$ & $29,10^{\mathrm{e}}$ & $0,20^{\mathrm{d}}$ & $3,90^{\mathrm{a}}$ & $0,986^{\mathrm{a}}$ & $147,81^{\mathrm{b}}$ & $12,79^{\mathrm{c}}$ \\
SL2 & 79,64 & $15,03^{\mathrm{b}}$ & $28,02^{\mathrm{b}}$ & $29,40^{\mathrm{e}}$ & $0,25^{\mathrm{b}}$ & $3,75^{\mathrm{b}}$ & $0,984^{\mathrm{ab}}$ & $118,44^{\mathrm{d}}$ & $12,63^{\mathrm{c}}$ \\
SL3 & 85,25 & $16,05^{\mathrm{ab}}$ & $36,48^{\mathrm{a}}$ & $39,00^{\mathrm{a}}$ & $0,20^{\mathrm{d}}$ & $3,85^{\mathrm{a}}$ & $0,975^{\mathrm{bc}}$ & $196,52^{\mathrm{a}}$ & $17,97^{\mathrm{a}}$ \\
SL4 & 79,29 & $15,25^{\mathrm{b}}$ & $33,40^{\mathrm{a}}$ & $38,00^{\mathrm{b}}$ & $0,28^{\mathrm{a}}$ & $3,74^{\mathrm{b}}$ & $0,970^{\mathrm{c}}$ & $138,13^{\mathrm{c}}$ & $17,61^{\mathrm{a}}$ \\
SL5 & 81,38 & $15,65^{\mathrm{ab}}$ & $31,71^{\mathrm{ab}}$ & $34,10^{\mathrm{c}}$ & $0,24^{\mathrm{c}}$ & $3,85^{\mathrm{a}}$ & $0,981^{\mathrm{ab}}$ & $143,51^{\mathrm{bc}}$ & $15,47^{\mathrm{b}}$ \\
SL6 & 81,54 & $15,55^{\mathrm{ab}}$ & $31,74^{\mathrm{ab}}$ & $33,75^{\mathrm{cd}}$ & $0,24^{\mathrm{c}}$ & $3,79^{\mathrm{b}}$ & $0,983^{\mathrm{ab}}$ & $138,50^{\mathrm{c}}$ & $15,55^{\mathrm{b}}$ \\
SL7 & 81,69 & $15,50^{\mathrm{b}}$ & $31,37^{\mathrm{ab}}$ & $33,30^{\mathrm{d}}$ & $0,24^{\mathrm{c}}$ & $3,78^{\mathrm{b}}$ & $0,982^{\mathrm{ab}}$ & $139,23^{\mathrm{c}}$ & $15,56^{\mathrm{b}}$ \\
\hline OA & 81,85 & 15,67 & 31,47 & 33,81 & 0,23 & 3,81 & 0,980 & 146,02 & 15,37 \\
SMD & - & 1,17 & 5,14 & 0,47 & 0,01 & 0,06 & 0,009 & 6,74 & 0,61 \\
CV(\%) & - & 2,67 & 5,85 & 0,50 & 1,24 & 0,54 & 0,33 & 1,66 & 1,42 \\
Fcal. & - & $5,13^{* *}$ & $8,27^{* *}$ & $1494,58^{* *}$ & $277,45^{* *}$ & $24,87^{* *}$ & $9,032^{* *}$ & $298,19^{* *}$ & $273,93^{* *}$ \\
\hline
\end{tabular}

EXP - Experiment; SL1...SL7 - Soursop liquor; I - Income; AC - Alcohol content; DR - dry residue; TSS - total soluble solids; TTA - Total titratable acidity in citric acid; $\mathrm{a}_{\mathrm{w}}$ - Water activity; TS - Total sugars; Means followed by the same letter in the column do not differ statistically at $5 \%$ probability by the Tukey test; OA - Overall average; SMD - Significant mean deviation; CV - Coefficient of variation; Fcal. - calculated F; ** - Significant at $1 \%$ probability by the F test. 
The liquors formulated with the highest pulp concentrations (SL2 and SL4) had the lowest yields (79.64 and $79.29 \%$, respectively), followed by the formulations with intermediate concentrations of soursop (SL5 to SL7). As these drinks of the largest pulp concentrations were added, at the end of filtration, the highest amounts of residue were yielded, consisting of the fruit fibers, affecting the final mass balance of liquors and, consequently, the yield.

All liquors had alcohol contents within the range established by the Brazilian legislation (BRASIL, 2009), which determines variation of 15 to $54 \%(\mathrm{v} / \mathrm{v})$ alcohol. The higher alcohol levels were obtained in liquors SL1 $(16.69 \% \mathrm{v} / \mathrm{v})$ and SL3 $(16.05 \% \mathrm{v} / \mathrm{v})$, formulated with the lowest concentration of pulp, which can be associated with less dilution of the alcohol promoted by minor addition of soursop. Oliveira and Santos (2011), studying the achievement and evaluation of açaí liquor, found an alcohol content $(16 \% \mathrm{v} / \mathrm{v})$ close to the result of this work, while Dias et al. (2011), evaluating the physical and chemical characteristics of yellow passion fruit liquor, obtained a higher value $(21 \% \mathrm{v} / \mathrm{v})$.

The dry residue was between $27.56 \%$ (SL1) and $36.48 \%$ (SL3), being lower than the values obtained by Viana et al. (2011), who were developing and characterizing tangerine peel liquors with different alcoholic bases (42.71 to $46.53 \%$ ). It was observed that the soursop liquors formulated with the lowest (SL1 and SL2) and highest (SL3 and SL4) syrup TSS contents were statistically different $(p<0.05)$, yet the former beverages, formulated with syrup at $70{ }^{\circ}$ Brix, had the highest dry residues (36.48 and $33.40 \%$ ). This probably can be related to the interference of sucrose. Since sucrose was present as a solid, it dissolved in greater proportion in this syrup, which affected the amount of solids (residue) obtained after the alcohol evaporation.

As expected, the different TSS contents of the syrups affected the TSS content of the drinks, where the liquors processed with syrup at $50^{\circ}$ Brix were the only ones to exhibit values below $30{ }^{\circ}$ Brix. In absolute values, the TSS ranged from $29.10{ }^{\circ}$ Brix (SL1) to $39{ }^{\circ}$ Brix (SL3), similar to the values reported by Barros et al. (2008) and Viera et al. (2010) when characterizing liquors of milk (27 ${ }^{\circ}$ Brix) and camu-camu ( $33^{\circ}$ Brix $)$, respectively.

The beverages formulated with the lowest concentrations of pulp (SL1 and SL3) showed the lowest values for TTA $(0.20$ and $0.20 \%)$. In contrast, the formulations with the highest concentrations of pulp (SL2 and SL4) had the highest values for this parameter $(0.25$ and $0.28 \%)$. During maceration, in addition to the drag of substances responsible for sensory characteristics, such as pigments and volatile compounds, there is also the solubility in the alcohol of chemical components from the pulp, such as sugars and organic acids. This justifies the higher acidity values in the formulations with higher proportions of soursop pulp. In the study by Teixeira et al. (2005), lower TTA levels in banana liquors $(0.06$ to $0.11 \%)$ was evidenced, due to the feature of less acidity of the pulp used in the processing compared to the pulp of soursop.

The $\mathrm{pH}$ values ranged between 3.74 (SL4) and 3.90 (SL1), being mainly affected by the pulp proportions. It was found that the liquors processed with $500 \mathrm{~g}$ of soursop (Table 1) showed a stronger acidic $\mathrm{pH}$, which is related to higher extraction of organic acids in maceration. As the acidity and the $\mathrm{pH}$ are inversely proportional magnitudes, this increased extraction led to the achievement of lower $\mathrm{pH}$ values at the end of maceration. Franco and Landgraf (2005) reported that low $\mathrm{pH}$ values are important because they are a limiting factor for the growth of pathogenic and spoilage bacteria, in addition to favoring the stability of some constituents, such as ascorbic acid, as this vitamin has greater stability in acidic $\mathrm{pH}$. Simões et al. (2011) found in pineapple liquor a higher $\mathrm{pH}$ (4.45) to that found for the soursop liquors in this research. Yet, Oliveira and Santos (2011) reported a similar $\mathrm{pH}$ in açaí liquor (3.52).

The water activity showed to be lower than 0.98 only in beverages processed with syrup with the highest TSS content (SL3 and SL4), due to the ability of sucrose to form strong bonds with the free water, thereby not preventing its use by microorganisms. Despite these values, there is need for efficient thermal treatment application in all beverages to ensure better microbiological stability during marketing, such as the unwanted conversion of ethyl alcohol into acetic acid.

The TSS/TTA ratio ranged from 118.44 (SL2) to 196.52 (SL3). Similar values of the TSS/ TTA ratio were found by Barros et al. (2008) studying milk liquors (192.86). The high values for this relationship were expected, since the drinks exhibited high levels of TSS at the end of processing and low levels of TTA. Knowing that the TSS/TTA ratio is an important indicator of taste, as it relates the dissolved solids such as sugars and acids present in the product, it was found that the SL3 formulation appeared to be perceptibly sweeter, due mainly to lower values of TTA provided by the minor addition of pulp and higher concentration of sugars of the syrup used ( $70^{\circ}$ Brix).

The different TSS of the sucrose syrups used in the liquor formulations also influenced the total sugar values (Table 3), in that the beverages made with syrup with higher TSS contents (SL3 and SL4) showed the highest levels of total sugars, followed by drinks with intermediate syrup TSS (SL5 to SL7). The total sugar content of soursop liquors ranged from 12.63 to $17.97 \%$, in accordance with the standards specified by the Brazilian legislation (BRASIL, 2009), which specifies a minimum total sugar content of $3 \%(30 \mathrm{~g} / \mathrm{L})$ for that drink. 
Total sugars did not differ among themselves $(p<0.05)$ for the formulations prepared with the same contents of TSS of syrups, according to the statistical test applied. Nogueira and Venturini Filho (2005) when studying acerola liquors found values between 30.03 and $32.05 \%$, and Dias et al. (2011) published an average value of $26.42 \%$ of total sugars in liquor from cuts of the yellow passion fruit.

The soursop liquors showed to be clear. They exhibited $L^{*}$ values greater than 55 , with little intense (0.66 to 1.22$)$ red tint $\left(+\mathrm{a}^{*}\right)$, and more evident yellowing tint $\left(+b^{*}\right)$ (10.64 to 14.61$)$, which may have been affected by the addition of syrups presented with light amber coloration (Table 4). The SL4 formulation, prepared with the highest concentrations of pulp and syrup TSS, had the lowest values of $L^{*}$ and $+a^{*}$ but the highest value of $+b^{*}$, indicating more opaque coloration, with more intense yellow hue. Yet, the SL1 formulation, prepared with the lowest concentrations of pulp and syrup TSS, had the lowest value of $+b^{*}$, indicating that as the processing variables increased, the liquors tended to become more yellowish.

Table 4. Average values of the soursop liquor colorimetric analysis.

\begin{tabular}{cccc}
\hline & \multicolumn{3}{c}{ Resposta } \\
\cline { 2 - 4 } EXP & L* $^{*}$ & $+\mathrm{a}^{*}$ & $+\mathrm{b}^{*}$ \\
\hline SLG1 & $61,27^{\mathrm{a}}$ & $1,07^{\mathrm{b}}$ & $10,64^{\mathrm{f}}$ \\
SLG2 & $58,57^{\mathrm{d}}$ & $1,22^{\mathrm{a}}$ & $12,31^{\mathrm{d}}$ \\
SLG3 & $60,89^{\mathrm{b}}$ & $1,07^{\mathrm{b}}$ & $11,65^{\mathrm{e}}$ \\
SLG4 & $55,71^{\mathrm{e}}$ & $0,66^{\mathrm{d}}$ & $14,61^{\mathrm{a}}$ \\
SLG5 & $60,91^{\mathrm{b}}$ & $0,88^{\mathrm{c}}$ & $12,13^{\mathrm{d}}$ \\
SLG6 & $59,70^{\mathrm{c}}$ & $0,71^{\mathrm{d}}$ & $12,76^{\mathrm{c}}$ \\
SLG7 & $61,43^{\mathrm{a}}$ & $1,08^{\mathrm{b}}$ & $13,41^{\mathrm{b}}$ \\
\hline OA & 59,78 & 0,96 & 12,50 \\
MSD & 0,20 & 0.10 & 0,37 \\
CV (\%) & 0,12 & 3,75 & 1,07 \\
Fcal. & $2457,88^{* *}$ & $104,31^{* *}$ & $273,51^{* *}$ \\
\hline
\end{tabular}

EXP - Experiment; SL1...SL7 - Soursop liquor; L* - Luminosity; $+a^{*}$ - Red intensity; $+b^{*}$ - Yellow intensity. Means followed by the same letter in the column do not differ statistically at 5\% probability by the Tukey test; OA - Overall average; MSD - Mean significant deviation; $\mathrm{CV}$ - Coefficient of variation; Fcal. - calculated $\mathrm{F}$; ** - significant at $1 \%$ probability by the $\mathrm{F}$ test.

As for the experimental design, the results of the physical and chemical characterization provided first-order models with an interaction and a 95\% confidence interval. Analyses of the effects for each response were performed, and, when possible $\left(\mathrm{F}_{\mathrm{c}} \geq\right.$ $\left.F_{\text {tab }}\right)$, the statistically significant models were checked. Importantly, each response was analyzed separately, according to the model generated.

The statistical analysis allowed for the determination of the regression coefficients, calculated $\mathrm{F}$ values, $\mathrm{R}^{2}$ values and mathematical equations for all responses (Table 5). It was observed that the models adjusted to the data of yield, alcohol content, dry residue, TSS, TTA, TSS/TTA ratio and total sugars were significant $\left(\mathrm{F}_{\mathrm{c}} / \mathrm{F}_{\mathrm{tab}} \geq 1.0\right)$, revealing good adjustment to the experimental data, with data of $\mathrm{R}^{2}$ values greater than 0.94 . It was also found that the models adjusted to the experimental data of yield, dry residue, TSS, TTA and total sugars, in addition to being significant, were also predictive, as they presented values of the $F_{c} / F_{\text {tab }}$ ratio exceeding 4 at the $95 \%$ confidence level. The models adjusted to the other responses $\left(\mathrm{pH}, \mathrm{a}_{\mathrm{w}}, \mathrm{L}^{*},+\mathrm{a}^{*}\right.$ and $\left.+\mathrm{b}^{*}\right)$ revealed lower adjustments, with $\mathrm{R}^{2}$ values ranging from $0.6555\left(+\mathrm{a}^{*}\right)$ to $0.8899\left(\mathrm{~A}_{\mathrm{w}}\right)$ and $\mathrm{F}_{\mathrm{c}} / \mathrm{F}_{\text {tab }}$ ratios lower than 1 at $95 \%$ confidence levels, confirming that the regressions were not significant.

The individual effects of pulp concentration 
and syrup TSS content, as the effects of the interaction thereof on the response variables, are shown via the Pareto diagram (Figure 1). In each diagram, the factors showing the strongest influence for each response were verified.

The pulp concentration showed significant effects on income, alcohol content, dry residue, TTA, TSS/TTA ratio and luminosity. The pulp concentration is onsidered the most significant effect when compared with the TSS content of the syrup that, in turn, had significant effects on the dry residue content, the final TSS of the liquor, the $a_{w}$, the TSS/TTA ratio and the total sugars. It was also found that the interaction between the concentration of pulp and the TSS content of the syrup showed significant effects only on the income, alcohol content, dry residue and TSS/TTA ratio.

Table 5. Results of the regression analyses to data from the physical and chemical characterization of soursop liquors at the $95 \%$ confidence interval.

\begin{tabular}{cccccl}
\hline Response & $\mathrm{R}^{2}$ & $\mathrm{~F}_{\mathrm{c}}$ & $\mathrm{F}_{\mathrm{tab}}$ & $\mathrm{F}_{\mathrm{c}} / \mathrm{F}_{\mathrm{tab}}$ & \multicolumn{1}{c}{ Equation } \\
\hline $\mathrm{I}$ & 0,9802 & 49,55 & 9,28 & 5,34 & $82,66643-0,00477 \mathrm{P}+0,16125 \mathrm{TSS}-0,00036 \mathrm{P} / \mathrm{TSS}$ \\
$\mathrm{AC}$ & 0,9601 & 24,04 & 9,28 & 2,59 & $23,92429-0,01905 \mathrm{P}-0,0965 \mathrm{TSS}+0,00022 \mathrm{P} / \mathrm{TSS}$ \\
$\mathrm{DR}$ & 0,9967 & 303,23 & 9,28 & 32,68 & $-8,60143+0,04655 \mathrm{P}+0,7115 \mathrm{TSS}-0,00088 \mathrm{P} / \mathrm{TSS}$ \\
$\mathrm{TSS}$ & 0,9958 & 236,14 & 9,28 & 25,45 & $-1,04286+0,01775 \mathrm{P}+0,5925 \mathrm{TSS}-0,00033 \mathrm{P} / \mathrm{TSS}$ \\
$\mathrm{pH}$ & 0,8631 & 6,31 & 9,28 & 0,68 & $4,398571-0,00125 \mathrm{P}-0,0055 \mathrm{TSS}+0,00001 \mathrm{P} / \mathrm{TSS}$ \\
$\mathrm{a}_{\mathrm{w}}$ & 0,8899 & 8,08 & 9,28 & 0,87 & $1,003907+0,000033 \mathrm{P}-0,000268 \mathrm{TSS}-0,000001 \mathrm{P} / \mathrm{TSS}$ \\
TTA & 0,9798 & 48,48 & 9,28 & 5,22 & $0,240714-0,000125 \mathrm{P}-0,00225 \mathrm{TSS}+0,000007 \mathrm{P} / \mathrm{TSS}$ \\
Relation & 0,9484 & 18,40 & 9,28 & 1,98 & $-42,94+0,2159 \mathrm{P}+4,612 \mathrm{TSS}-0,0073 \mathrm{P} / \mathrm{SST}$ \\
TSS/TTA & 0,9948 & 190,20 & 9,28 & 20,50 & $-0,551429+0,0017 \mathrm{P}+0,274 \mathrm{TSS}-0,00005 \mathrm{P} / \mathrm{TSS}$ \\
TS & 0,7724 & 3,39 & 9,28 & 0,37 & $57,64286+0,0175 \mathrm{P}+0,167 \mathrm{TSS}-0,00062 \mathrm{P} / \mathrm{TSS}$ \\
$\mathrm{L} *$ & 0,6555 & 1,90 & 9,28 & 0,21 & $-1,30429+0,00775 \mathrm{P}+0,042 \mathrm{TSS}-0,00014 \mathrm{P} / \mathrm{TSS}$ \\
$+\mathrm{a}^{*}$ & 0,8775 & 7,16 & 9,28 & 0,77 & $10,64643-0,00778 \mathrm{P}-0,04625 \mathrm{TSS}+0,00032 \mathrm{P} / \mathrm{TSS}$ \\
$+\mathrm{b}^{*}$ & &
\end{tabular}

$\mathrm{R}^{2}$ - Coefficient of determination; $\mathrm{F}_{\mathrm{c}}$ - calculated $\mathrm{F} ; \mathrm{F}_{\mathrm{tab}}$ - tabulated F; I - Income; AC - Alcohol content; DR - Dry residue; TSS - Total soluble solids; $\mathrm{a}_{\mathrm{w}}$ - Water activity; TTA - Total titratable acidity in citric acid; TS - Total sugars; L* - Luminosity; $+\mathrm{a}^{*}$ - Red intensity; $+\mathrm{b}^{*}$ - Yellow intensity; P - Pulp; TSS - Total soluble solids in the sucrose syrup

Figure 2 presents the response surfaces of the parameters that showed significant models $\left(\mathrm{F}_{\mathrm{c}} / \mathrm{F}_{\text {tab }}{ }^{3}\right.$ 1.0). It was found that with the increase in the TSS of the syrup, there were higher values of dry residue, total sugars and TSS contents of liquors. Yet, with increasing concentration of pulp, there were higher TTA values. It was observed that with the increase of syrup TSS content and the reduction in the concentration of pulp, the highest values were in relation to income and the TSS/TTA ratio. As for the alcohol content, the highest values were found with the reduction both of the pulp concentration and of the syrup TSS content, since they promoted alcohol dilution. 

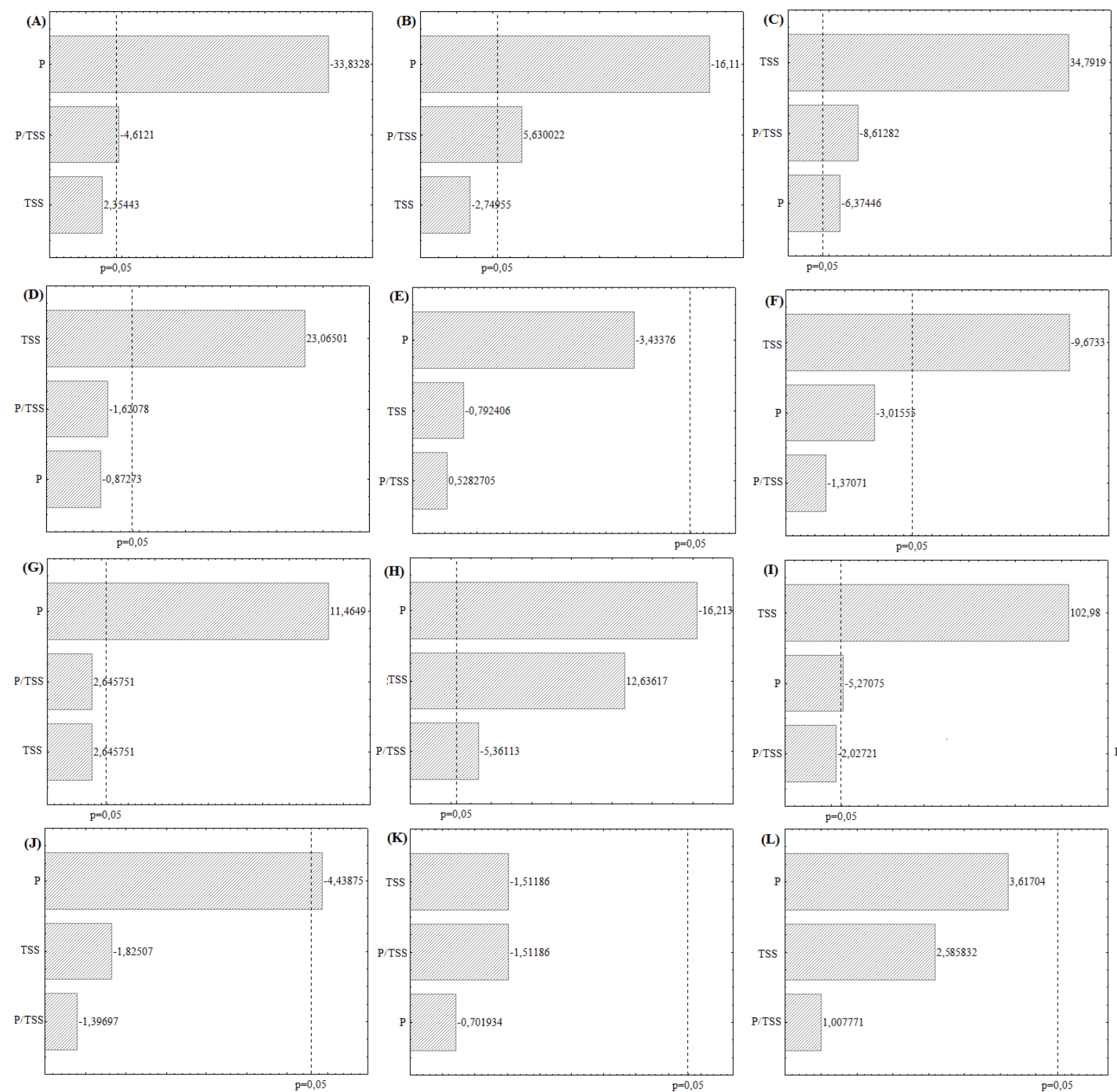

Figure 1. Pareto diagram for the influence of the factors of pulp (P), total soluble solids (TSS) of the syrup and their interaction (P/TSS) on the income (A), alcohol content (B), dry residue (C), TSS (D), pH (E), water activity $(\mathrm{F})$, total titratable acidity $(\mathrm{G})$, TSS/total titratable acidity ratio $(\mathrm{H})$, total sugars $(\mathrm{I})$, luminosity $(\mathrm{J})$, red intensity $(\mathrm{K})$ and yellow intensity (L) of the soursop liquors. 

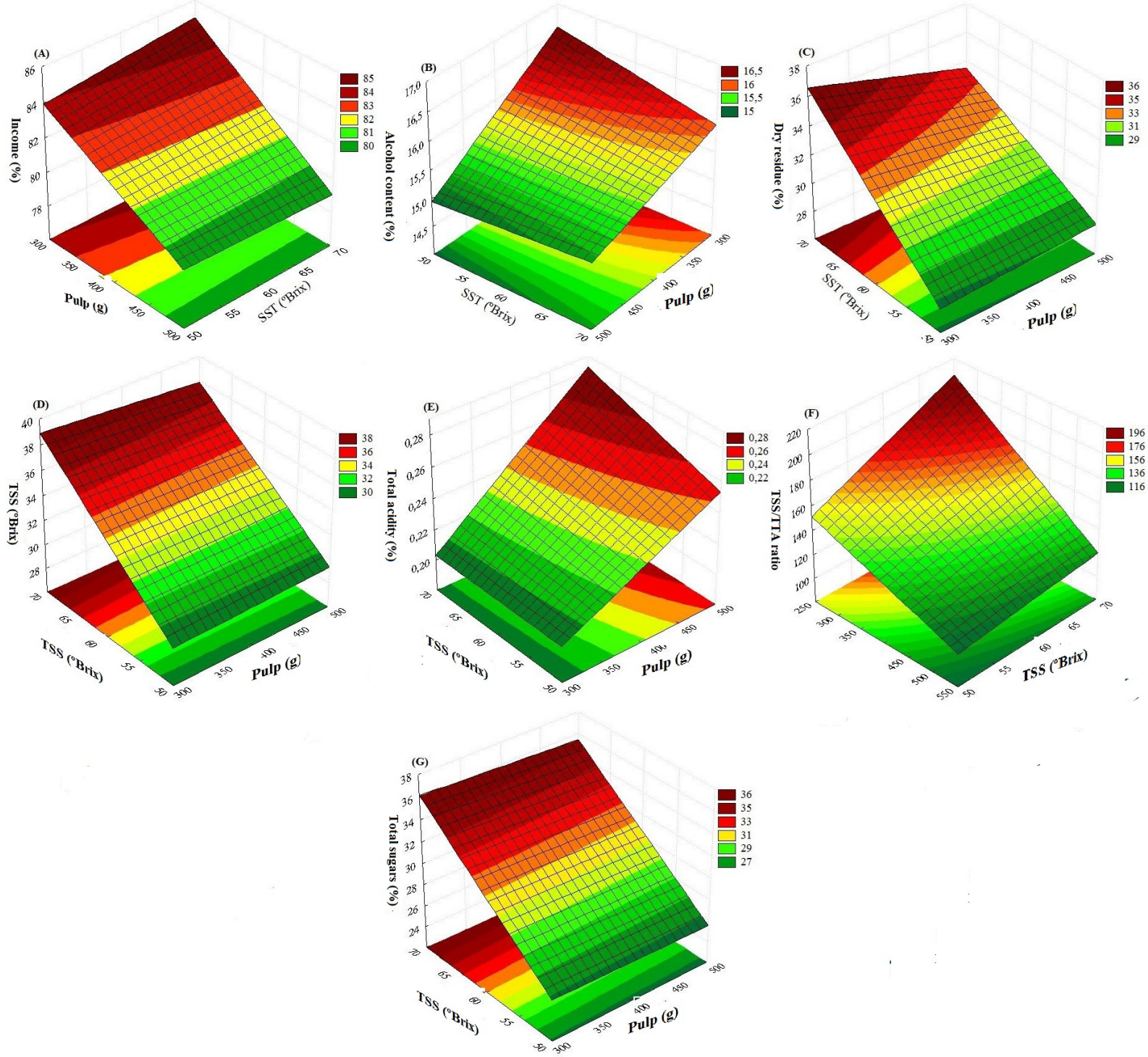

Figure 2. Response surfaces to yield (E), alcohol content (B), dry residue (C), total soluble solids (TSS) (D), total titratable acidity (E), TSS/TTA ratio (F) and total sugars $(\mathrm{G})$ of the soursop liquors, depending on the pulp (P) concentration and the content of TSS of the syrup.

\section{CONCLUSION}

Based on the foregoing information, the models adjusted to the experimental data of yield, dry residue, TSS, acidity and total sugars were significant and predictive, presenting $\mathrm{R}^{2}$ values greater than 0.97 . The responses of $\mathrm{pH}$, water activity, luminosity and intensities of red and yellow showed lower adjustments of the mathematical models, with $\mathrm{R}^{2}$ values less than 0.90 .

Soursop pulp was the most significant factor, influencing a larger number of responses (yield, alcohol content, dry residue, acidity, TSS/TTA ratio, total sugars and luminosity) compared with the content of TSS of the syrup and the interaction between both factors.

\section{REFERENCES}

ASSOCIATION OF OFFICIAL ANALYTICAL CHEMISTS - AOAC. Official Methods of Analysis, 14 ed. Washington, EUA, 1997. 1041p.

ASSOCIATION OF OFFICIAL ANALYTICAL CHEMISTS - AOAC. Official Methods of Analysis, 18 ed. Washington, EUA, 2010. 1094 p.

BARROS, J. C. et al. Obtenção e avaliação de licor de leite a partir de diferentes fontes alcoólicas. Global Science and Technology, Rio Verde, v. 1, n. 4, p. 27-33, 2008.

BENASSI, M. T.; ANTUNES, A. J. A. Comparison of meta-phosphoric and oxalic acids as extractant solutions for determination of vitamin $\mathrm{C}$ in selected vegetables. Arquivos de Biologia e Tecnologia, 
Curitiba, v. 31, n. 4, p. 507-503, 1998.

BRASIL. Ministério da Agricultura Pecuária e Abastecimento. Portaria ${ }^{\circ} 76$, de 27 de novembro 1986. Diário Oficial [da] Republica Federativa do Brasil, Brasília-DF, 03-12-86. Seção I, p. 18.15218173, 1986.

BRASIL. Ministério da Agricultura, pecuária e Abastecimento. Instrução Normativa $\mathrm{n}^{\circ} 01$, de 7 de Janeiro de 2000. Regulamento da Lei $\mathrm{n}^{\mathrm{o}} 8.918$, de 14 julho de 1994, aprovado pelo Decreto $n^{\circ} 2.314$, de 4 de setembro de 1997, que dispõe sobre o regulamento técnico geral para fixação dos padrões de identidade e qualidade para polpa de fruta. Diário Oficial [da] Republica Federativa do Brasil. Brasília, DF, 07 de Janeiro de 2000.

BRASIL. Ministério da Saúde. Agência Nacional de Vigilância Sanitária-ANVISA. Rotulagem nutricional obrigatória: manual de orientação às indústrias de Alimentos. $2^{\text {a }}$ Versão. Universidade de Brasília, Brasília, DF, 2005.

BRASIL. Ministério da Agricultura, Pecuária e Abastecimento. Decreto $\mathrm{n}^{\circ} 6.871$, de 4 de Julho de 2009. Dispõe sobre a padronização, a classificação, o registro, a inspeção, a produção e a fiscalização de bebidas. Diário Oficial [da] Republica Federativa do Brasil. Brasília, DF, 05 de jun. 2009.

CANUTO, G. A. B. et al. Caracterização físicoquímica de polpas de frutas da amazônia e sua correlação com a atividade anti-radical livre. Revista Brasileira de Fruticultura, Jaboticabal, v. 32, n. 4, p. 1196-1205, 2010.

CARVAlho, R. F. Produção de licores. 1 ed. Dossiê técnico. Rede de Tecnologia da Bahia, Salvador, BA, 2007. 27 p.

CARVALHO, A. V. et al. Características físicas, químicas e atividade antioxidante de frutos de matrizes de cajazeira no estado do Pará. Alimentos e Nutrição, Araraquara, v. 22, n. 1, p. 45-53, 2011.

CAVICHIOLI, J. C.; RUGGIERO, C.; VOLPE, C. A. Caracterização físico-química de frutos de maracujazeiro-amarelo submetidos à iluminação artificial, irrigação e sombreamento. Revista Brasileira de Fruticultura, Jaboticabal, v. 30, n. 3, p. 649-656, 2008.

DIAS, S. C. et al. Caracterização físico-química e sensorial do licor de corte do maracujá amarelo. Enciclopédia Biosfera, Goiânia, v. 7, n. 13, p. 1405 1412, 2011.

FRANCO, B. D. G.M.; LANDGRAF, M. Microbiologia dos alimentos. 1 ed. São Paulo, SP,
2005. 196 p.

INSTITUTO ADOLFO LUTZ - IAL. Normas analíticas, métodos químicos e físicos para análises de alimentos. 4 ed., 1 ed. digital, São Paulo, SP, 2008. 1020 p.

LIMA, M. A. C.; ALVES, R. E.; FILGUEIRAS, H. A. C. Comportamento respiratório e amaciamento de graviola (Annona muricata L.) após tratamentos póscolheita com cera e 1-metilciclopropeno. Ciência e Agrotecnologia, Lavras, v. 34, n. 1, p. 155-162, 2010.

MACIEL, M. I. S. et al. Caracterização físicoquímica de frutos de genótipos de aceroleira (Malpighia emarginata D.C.). Ciência e Tecnologia de Alimentos, Campinas, v. 30, n. 4, p. 865-869, 2010 .

MARCELLINI, P. S. et al. Comparação físicoquímica e sensorial da atemóia com a pinha e a graviola produzidas e comercializadas no estado de Sergipe. Alimentos e Nutrição, Araraquara, v. 14, n. 2, p. 187-189, 2003.

NOGUEIRA, A. M. P.; VENTURINI FILHO, W. G. Ultra e microfiltração de licor de acerola. Brazilian Journal of Food Technology, Campinas, v. 8, n. 4, p. 305-311, 2005.

OLIVEIRA, L. C. et al. Efeito de diferentes substratos na germinação de sementes e formação inicial de plântulas de graviola. Revista Verde de Agroecologia e Desenvolvimento Sustentável, Mossoró, v. 4, n. 1, p. 90-97, 2009.

OLIVEIRA, E. N. A.; SANTOS, D. C. Processamento e avaliação da qualidade de licor de açaí (Euterpe oleracea Mart.). Revista do Instituto Adolfo Lutz, São Paulo, v. 70, n. 4, p. 534-41, 2011.

PEREIRA, J. M. A. T. K. et al. Avaliação da Qualidade físico-química, microbiológica e microscópica de polpas de frutas congeladas comercializadas na cidade de Viçosa-MG. Alimentos e Nutrição, Araraquara, v. 17, n. 4, p. 437-442, 2006

SAMARÃO, S. S. et al. Desempenho de mudas de gravioleira inoculadas com fungos micorrízicos arbusculares em solo não-esterilizado, com diferentes doses de fósforo. Acta Scientiarum. Agronomy, Maringá, v. 33, n. 1, p. 81-88, 2011.

SIMÕES, L. S. et al. Estudo da cinética de extração alcoólica do processamento do licor de abacaxi. Enciclopédia Biosfera, Goiânia, v. 7, n. 13, p. 717 726, 2011 
TEIXEIRA, L. J. Q. et al. Avaliação tecnológica da extração alcoólica no processamento de licor de banana. Boletim do Centro de Pesquisa e Processamento de Alimentos, Curitiba, v. 23, n. 2, p. $329-346,2005$.

TEIXEIRA, C. K. B.; NEVES, E. C. A.; PENA, R. S. Estudo da pasteurização da polpa de graviola. Alimentos e Nutrição, Araraquara, v. 17, n. 3, p. 251-257, 2006.

TEIXEIRA, L. J. Q. et al. Testes de aceitabilidade do licores de banana. Revista Brasileira de Agrociência, Pelotas, v. 13, n. 2, p. 205-209, 2007.

VIANA, L. F. et al. Development and characterization of the tangerine peel liquor with different alcoholic bases. Acta Scientiarum. Technology, Maringá, v. 33, n. 1, p. 95-100, 2011.

VIERA, V. B. et al. Produção, caracterização e aceitabilidade de licor de camu-camu (Myrciaria dúbia (H.B.K.) McVaugh). Alimentos e Nutrição, Araraquara, v. 21, n. 4, p. 519-522, 2010. 